\title{
Diabetes Mellitus and Renal Aquaporins (AQPs)
}

\author{
Şengül $\mathrm{E}^{1}$ and Gelen $\mathrm{V}^{2 *}$ \\ ${ }^{1}$ Department of Physiology, Atatürk University, Turkey \\ ${ }^{2}$ Department of Physiology, Kafkas University, Turkey
}

Submission: March 06, 2017; Published: April 27, 2017

*Corresponding author: Volkan Gelen, Department of Physiology, Veterinary Faculty, Kafkas University, Turkey, Tel: 5382038744;

Email: gelen_volkan@hotmail.com

\section{Introduction}

Diabetes mellitus is defined by the elevation of fasting blood sugar and fasting and it is a disease characterized by impaired carbohydrate, lipid and protein metabolism. The frequency of diabetes has become a rapidly growing public problem and threatening the whole world Satman et al. [1]. The number of diabetics in the world was 194 million in 2003, and this number is reported to reach 246 million in 2007 Satman [2]. It is estimated that this number will increase further International Diabetes Federation (2013). According to estimates, before 2025, the number of diabetics will rise to over 380 million [3]. According to the TURDEP-I study in Turkey, there were a total of 5 million diabetics in 2002. According to the TURDEP-II study results, the rate of diabetic patients in Turkey was increased to 13.7 in 2010, while $7.8 \%$ in 2002. This data are shows that diabetes mellitus is a health problem that need to be meticulously focused. Diabetes mellitus causes damage to many organs and tissues. Renal damage induced by diabetes is one of them [4].

In the nephropathy and polyuria in the kidney are disturbing the body water balance. Intracellular, intercellular and extracellular water rates are kept in constant balance with homeostatic mechanisms [5]. Cells are surrounded by cell membranes called plasma membranes that separate the intracellular and extracellular area. The cell is tasked with providing the necessary conditions for the survival of the hostile lifestyle. The water can be passed by simple diffusion the plasma membrane, but the rapid and intensive passage of water is thanks to special channels for this work. The passage from the plasma membrane of water has been a topic of interest to researchers for many years. In 1993, Smith et al. [6] identified the water channel known as CHIP28 on the plasma membrane of erythrocytes (1993). In 1991, Preston and colleagues has showed as a water channel molecule the CHIP28 [7]. In 1993, Fusihimi [8] and his colleagues identified another form that served as a water channel in the renal collecting duct [8]. Agre and colleagues has give the aquaporin (AQP) name to water channel proteins [9]. Later years, studies have determined that in the cell membrane of mammalsfound13 different channels. These channels are named as AQP0-AQP12 [10]. These channels have been identified in many tissues such as kidney, lung, liver, brain and secretary gland [11].

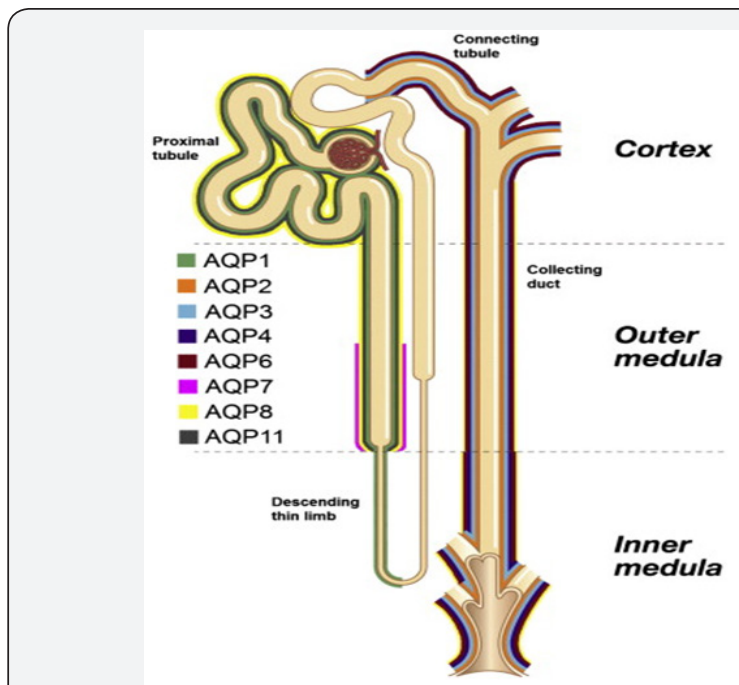

Figure 1: Location and distribution of AQPs in various parts of nephron Kortenoeven and Fenton (2014).

As the studies progressed, it was determined that these channel proteins are varied in function, structure and phylogenetics. For example: AQP3, AQP7 and AQP9 passes in glycerol as much as in water. For this reason they are also called aquagliseroporins [12]. AQP1, AQP2, AQP4 and AQP5 pass only the water. AQP5 is commonly found in tears, duodenal, pyloric and intestinal glands. In the kidney, at least 8 types such as AQP1, AQP2, AQP3, AQP4, AQP6, AQP7, AQP8 and AQP11 have identified [13] (Figure 1). From the AQP1 passes Approximately 109 water molecules. Aquaporins are very important because they provide fluid exchange between placenta and fetal membranes. They are tasked in cerebrospinal fluid formation during normal brain development. Before implantation, the blastocyst is filled with liquid released during the developmental phase of trophectoderm epithelium around the cavity [14-16]. 
AQPs, which are found in many parts of the organism and play a very important role in water balance, also have important roles in kidney tissue. In the various parts of the nephron, is the functional unit of the kidney have been identified the different APQs [16].

AQP1, consisting of 269 amino acids, forms 3\% of the total membrane proteins in the kidney. AQP1 provides water reabsorption from tubule epithelial cells in proximal and descending Henle's thin convolutions [17-19]. It has been determined that there is a decrease in polyuria and urine concentrating ability in experimental AQP1 deficient mice. AQP1 insufficiency is maintained water reabsorption in the proximal tubule by compensating with AQP7. It has determined that AQP1 is also found in the proximal tubule, of apical and basolateral membrane of epithelial cells of the descending Henle. AQP2, which is 271 amino acids in length, is localized to the apical membrane of the parent cells of the collecting tubules. Vasopressin is attached to the V2 receptor at the basolateral membrane of the collecting tubule parent cell and is stimulated with adenylyl cyclase by activation of protein G3, which is guanosine triphosphate binding protein. Activated adenylate cyclase increases cyclic adenosine monophosphate (cAMP) synthesis. cAMP binds to the regulatory subunit of protein kinase A (PKA) and the catalytic unit of the PKA becomes active. As a result, the phosphorylation of AQP2 in intracellular vesicles is increased. AQP2 moves through the apical membrane through microtubule motor proteins. AQPs stick to the apical membrane through various receptors (VAMP2, syntaxin-4, NSF) and exocytosis comes into play.

At this stage, the passage into the cell from the tubule lumen of water is provided. Then, the AQP2 turns cell into from apical membrane cell and the water is taken in by endocytosis. Activation of promoter regions the cAMP responsive substance binding protein in the AQP2 gene is achieved by PKA and thereby increasing the synthesis of AQP2. AQP3, consisting of 292 amino acids, is found in the basolateral membrane of the parent cells of collecting tubules and AQP3 provides passage of water to the interstitial space in this region. Also, AQP3 is responsible for the passage of the urea as well as the water. It has been suggested that AQP3 has activity under the AVP effect. AQP4, which is 301 amino-acidic, is found on the basolateral membrane of collecting tubules in the medulla. AQP4 provides the transmission into the interstitial space from the tubule cells of the water. AQP6 and AQP7occurs of 276 and 269 amino acids, respectively. AQP6 is found in the renal cortex and medullary and AQP7 is present in apical membranes of the renal cortex.

The functions of AQP6 and AQP7 have not yet been fully obtained. As previously mentioned, AQP7 provides reabsorption of water from the proximal tubules in the inadequacy of AQP1, which prevents the inadequacy of this to reflect on the clinic of this situation. A variety of studies have identified the alteration of diabetes mellitus expression in AQP2, which has a significant relative in water metabolism [20]. Earlier, diabetic polyuria was thought that was originated from an osmotic diuresisas a result of hyperglycemia. However, recent studies have reported that polyuria is caused by AQPs and especially this is due to the decrease of AQP2 expression. It is thought that in the osmotic diuresis is shaped by the increase of blood vasopressin level. It has been previously determined that AQP2 plays a role in vasopressin-mediated water absorption in the kidney [21-23]. It was determined that the expression of AQP2 and AQP3 was increased in STZ-induced diabetes mellitus in mice [24].

\section{Conclusion}

For this reason, many researchers have been curious about the effects of various drugs on APQ2 and AQP3 excretion in the regulation of polyuria [25-27].

\section{References}

1. Satman I, Yilmaz T, Sengül A, Salman S, Salman F, et al. (2002) Population-basedstudy of diabetesand risk characteristics in Turkey: results of the turkishdiabetes epidemiology study (TURDEP)". Diabetes Care 25(9): 1551-1556.

2. Satman I ( 2011)Türk Endokronoloji ve Metabolizma Derneği.

3. Oto A (2011) Diabet ve Koroner Arter Hastalı̆̆: Gelişen Dünyanın Korkunç İkilisi. Türkiye Kardiovasküler Tıp Elektronik Dergisi.

4. Bherwani S, Saumya AS, Ahirwar AK, Sandhya AS, Prajapat B, et al. (2016) The association of folicacid deficiency and diabetic nephropathy in patients with type 2 diabetes mellitus. Endocr Metab Immune Disord Drug Targets.

5. Passe DH, Horn M, Stofan J, Murray R (2004) Palatability and voluntary intake of sports beverages, diluted orange juice, and water during exercise. Int J Sport Nutr Exerc Metab 14(3): 272-284.

6. Nielsen S, Smith BL, Christensen EI, Knepper MA, Agre P (1993) CHIP28 water channels are localized in constitutivelywater-permeable segments of the nephron. J Cell Biol 120(2): 371-383.

7. Preston GM, Agre P (1991) Isolation of thec DNA for erythrocyte integral membrane of 28 kilodaltons: Member of an ancient water channel family. Proc Natl Acad Sci U S A 88(24): 11110-11114.

8. Fushimi K, Uchida S, Hara Y, Hirata Y, Marumo F, et al. (1993) Cloning and expression of apical membrane water channel of rat kidney collecting tubule. Nature 361(6412): 549-552.

9. Agre P, Moon C, Preston GM, Griffin CA, Jabs EW (1993) The human aquaporin-CHIP gene. Structure, organization, and chromosomal localization. J Biol Chem 268(21): 15772-15778.

10. Fujiyoshi Y, Mitsuoka K, de Groot BL, Philippsen A, Grubmüller H, et al. (2002) Structure and function of water channels. Curr Opin Struct Biol 12(4): 509-515.

11. Ishibashi K, Hara S, Kondo S (2009) Aquapor in water channels in mammals. Clin Exp Nephrol 13(2): 107-117

12. Park JH, Saier MH (1996) Phylogenetic characterization of the MIP family of trans membrane channel proteins. J Membr Biol 153(3): 171180.

13. Kortenoeven ML, Fenton RA (2014) Renal Aquaporins and water balance disorders. Biochim Biophys Acta 1840(5): 1533-1549.

14. International Diabetes Federation(2013) Brussels, Belgium: International Diabetes Federation. IDF atlas (6th edn).

15. Kurcer Z, Parlakpinar H, Vardi N, Tasdemir S, Iraz M, et al. (2007) Protective effects of chronic melatonin treatment against 
renalischemia/reperfusion injury in streptozotocin-induced diabetic rats. Exp Clin Endocrinol Diabetes 115(6): 365-371.

16. Reiter RJ, Tan DX, Osuna C, Gitto E (2000) Action of melatonin in the reduction of oxidative stress. J Biomed Sci 7(6): 444-458.

17. Nielsen S, Kwon TH, Christensen BM, Promeneur D, Frøkiaer J, et al. (1999) Physiology and patophysiology of renal aquaporins. J Am Soc Nephrol 10(3): 647-663.

18. Van OCH, Deen PM (1998) Role of aquaporins in renal water handling: Physiology and patophysiology. Nephrol Dial Transplant 13(7): 16451651.

19. Martin PY, Schrier RW (1998) Role of aquaporin-2 water channels in urinary concentration and dilution defects. Kidney Int Suppl 65: S5762.

20. Leung JC, Chan LY, Tsang AW, Tang SC, Lai KN (2005) Differential expression of aquaporins in the kidneys of streptozotocin-induced diabeticmice. Nephrology (Carlton) 10(1): 63-72.

21. Schrier RW (2006) Body water homeostasis: clinical disorders of urinary dilution and concentration" J Am Soc Nephrol 17(7): 18201832.
22. Sabolić I, Katsura T, Verbavatz JM, Brown D (1995) The AQP2 water channel: effect of vasopress in treatment, microtubule disruption, and distribution in neonatal rats. J Membr Biol 143,(3): 165-175.

23. Hasler U, Vinciguerra M, Vandewalle A, Martin PY, Féraille E (2005) Dual effects of hypertonicity on aquaporin-2 expression in cultured renal collecting duct principal cells. J Am Soc Nephrol 16(6): 15711582.

24. Satake M, Ikarashi N, Kagami M, Ogiue N, Toda T, et al. (2010) Increases in the expression levels of aquaporin-2 and aquaporin-3 in the renal collecting tubules alleviate dehydration associated with polyuria in diabetesmellitus. Biol Pharm Bull 33(12): 1965-1970.

25. Reiter RJ, Tan DX, Poeggeler B, Menendez PA, Chen LD, et al. (1994) Melatonin as a free radical scavenger: implications for aging and agerelated diseases. Ann N Y Acad Sci 719: 1-12.

26. Rodriguez C, Mayo JC, Sainz RM, Antolín I, Herrera F, et al. (2004) Regulation of antioxidants enzymes: a significant role for melatonin. J Pineal Res 36(1): 1-9.

27. Rodríguez RS, Leal C, Portilla-de BE, Castillo JC, Ramos SF (2004) Melatonin ameliorates renal ischemia/reperfusion injury. J Surg Res 116(2): 242-247.

\section{Your next submission with Juniper Publishers will reach you the below assets}

- Quality Editorial service

- Swift Peer Review

- Reprints availability

- E-prints Service

- Manuscript Podcast for convenient understanding

- Global attainment for your research

- Manuscript accessibility in different formats ( Pdf, E-pub, Full Text, Audio)

- Unceasing customer service

Track the below URL for one-step submission https://juniperpublishers.com/online-submission.php 